\title{
Health Status of Children of Chepang and Other Communities of Nepal
}

\author{
Ghimire M. N. ${ }^{1}$ \\ ${ }^{1}$ PhD Scholar | Mewar University, Rajasthan, India \\ mayanathghimire@gmail.com
}

\begin{abstract}
Background: The study was conducted among the children and parents of Chepang community to know their health status in comparison with other communities. Chepang is an indigenous ethnic group living in Central and Southern Nepal especially in Chitawan, Gorkha and Dhading districts and also known as one of the isolated tribal groups of Nepal. They have their own language known as Chepang but is called Chyo-bang by the people themselves. The Chepang settlement is often on very steep land, unfertile and not easily accessible. Methods: The study was cross-sectional descriptive design. Simple random sampling technique was used to select the 38 children and their parents from the Brahmin/Chhetri, Ethnic groups, Chepang and Dalit. Result: Only 42\% respondents had reported that they had visited hospital for checkups during the time of pregnancy. Among them only 11\% Chepang had visited hospital. Similarly, 79\% reported the use of iron tablets during the pregnancy and after post-delivery periods. In the same way, 95\% reported that they had given birth to a child at home. In an average, $17 \%$ children of Chepang had better height, weight and thickness of arm than other communities' children. Conclusion: Chepang are found back in health seeking practices than the other communities. Cent percent mother had reported that they had given the birth of $1^{\text {st }}$ baby before 20 years of her age. Though, health status of Chepang children found better than other communities' children.
\end{abstract}

\section{KEYWORDS}

\author{
Chepang, Health, Nutrition
}

\section{INTRODUCTION}

The study was conducted to identify the health seeking behaviour and health status of the children of Chepang Community and other communities of the Chitwan district of Nepal. The Chepang is an indigenous group living in the Mountain range of Central Nepal. Over the past two or three generations the Chepangs have begun to shift slowly from a semi-nomadic (slash-and-burn) lifestyle to a more settled way of life, relying increasingly upon the produce of permanent fields of maize, millet and bananas. Chepangs, also called 'Prajas', are regarded as one of the marginalized and socio-economically deprived indigenous ethnic communities. They have lived a semi-nomadic life, and have depended enormously on the natural forest resources over a long period of time. Forests are the most important source for them in terms of food, fiber, fodder, medicine, housing materials and various other needs. Hunting and wild food collection has been their traditional living for subsistence and shifting cultivation (Khoriya) is the only feasible way to farm the steep slopes inhabited by them (Limbu, 2011). The traditional food practices are not sufficient to maintain their physical health well so there may be high chances of risk of malnutrition in children. Nutrition may be defined as the science of food and its relationship to health. It is concerned primarily with the role played by nutrients in body growth, development and maintenance. The nutrient or "food factor" used for specific dietary constituents are proteins, vitamins and minerals. Dietetics is the practical application of the principles of nutrition; it includes the planning of meals for the well and the sick. Good nutrition means "reformed a nutritional status that enables us to grow well and enjoy good health" (Park, 2007, p. 480). Malnutrition has been defined as "a pathological state resulting from a relative or absolute deficiency or excess of one or more essential nutrients" (Park, 2007, p. 415).

Malnutrition is a worldwide health problem especially in developing or underdeveloped countries. According to WHO 2003-2009, 16\% of under-five year children of India found suffered severely from underweight. Similarly, Sri Lanka 15\%, Pakistan $14 \%$, Bhutan $3 \%$ and $11 \%$ Nepalese under-five children found suffered from severe underweight. In relation to the nutritional problem in Nepal, the national nutrition programme under the Department of Health Services has laid the following vision "all Nepali people living with adequate nutrition, food safety and food security for adequate physical, mental and social growth and development and survival (Department of Health 
Services, 2011)" with the mission to improve the overall nutritional status of children, women of child bearing age, pregnant women, and all ages.

\section{METHODOLOGY}

Cross-sectional descriptive survey was done by using a well-structured questionnaire. Measurement of weight, height and thickness of arm of children was taken by using weighting machine and measuring tape to determine the nutritional status of 3-5 years children. Study was conducted in Chitwan districts of Nepal in Chepang community and other community groups to compare the health status. Altogether 38 children and their parents were selected for this study by using the simple random sampling method. Collected data and information were analyzed and interpreted with quantitative descriptive way. Data were analysed in the SPSS to show the percentage and cross tabulation.

\section{RESULT AND DISCUSSION}

The finding of the study has explored the comparative data of health status of Brahmin/Chhetri, Ethnic groups, Chepang and Dalit. In research, total 38 children were participated, among them $95 \%$ were males and 5\% were females. Similarly, $60 \%$ were Hindu, $11 \%$ from Buddhist and $29 \%$ were Christian. About three fourth (76\%) reported that they were living in the nuclear family and rest (24\%) were living in joint family.

To know the health status of mother and children of Chepang and other community, various questions were asked. The responses are tabulated and analyzed as below:

\begin{tabular}{|l|l|l|l|l|l|l|}
\hline Table 1. Age of mother having first child \\
\cline { 2 - 8 } Caste/Ethnicity & Less than 20 years & $\mathbf{2 0 - 2 5}$ years & \multicolumn{2}{l|}{ More than 30 years } \\
\cline { 2 - 8 } & $\#$ & $\mathbf{\%}$ & $\#$ & $\mathbf{\%}$ & $\#$ & \% \\
\hline Brahman/Chhetri & 2 & 67 & -1 & 33 & - & - \\
\hline Ethnic Group & 8 & 53 & 6 & 40 & 1 & 7 \\
\hline Chepang & 19 & 100 & - & - & - & - \\
\hline Dalit & 1 & 100 & - & - & - & - \\
\hline Total & 30 & 79 & 7 & 18 & 1 & 3 \\
\hline
\end{tabular}

Field Survey, 2013

The above table shows that, $79 \%$ mother had given the birth of first child in less than 20 years of her age. As compare between the four different groups, $100 \%$ respondents of Chepang and Dalit mothers had given birth to their $1^{\text {st }}$ baby before the age of 20 . The data clearly shows the culture of early marriage system in Chepang and other Dalit communities.

Out of 38 respondents, only $42 \%$ had reported that they had visited hospital for checkups during the time of pregnancy period.

\begin{tabular}{|c|c|c|c|c|c|c|}
\hline \multirow[b]{2}{*}{ Caste/Ethnicity } & \multicolumn{4}{|c|}{ Checking Times } & \multicolumn{2}{|l|}{ Total } \\
\hline & One time & Two times & Three times & Four times & \# & $\%$ \\
\hline Brahman/Chhetri & 1 & 0 & 2 & 0 & 3 & 100 \\
\hline Ethnic Group & 0 & 4 & 2 & 5 & 11 & 73 \\
\hline Chepang & 1 & 0 & 1 & 0 & 2 & 11 \\
\hline Dalit & 0 & 0 & 0 & 0 & 0 & 0 \\
\hline Total & $2(13 \%)$ & $4(25 \%)$ & $5(31 \%)$ & $5(31 \%)$ & $16(100 \%)$ & 42 \\
\hline
\end{tabular}

Field Survey, 2013

Among $42 \%$ of the respondents, $31 \%$ visited three and four times followed by $25 \%$ visited two times and $13 \%$ visited only one time. Comparatively, respondents from the Dalit community had not visited, only $11 \%$ Chepang, followed by $73 \%$ ethnic group and $100 \%$ Brahman and Chhetri had visited hospital for their health checkup. The data also presents that health seeking practices among 
the Chepang and other disadvantage community is found very poor which can bring the complication in the mother and child's health.

A previous study was carried out in ward no. 9 of Mahankal VDC, Kathmandu among the 50 women of reproductive age group who had delivered live birth five years preceding the survey. The result of the study shows that $78 \%$ of women were using the services. More notable fact was that the $62 \%$ of the respondents made antenatal visits for four or more than four times. Seventy two percent of the respondents y received the tetanus toxoid shots. Sixty six percent of the deliveries were hospital deliveries assisted by the doctors. However, $34 \%$ of deliveries occurred at home. The difference in ANC visit in different age groups and parity was not much obvious. The educational effect was clear as nearly double women who attained SLC or above, made four or more ANC visit as compared to illiterates (Pradhan, 2005).

Antenatal care from a trained provider is important in order to monitor the risks associated with pregnancy and delivery for the mother and her child. According to the 2011 NDHS, 58 percent of women who gave birth in the 5 years preceding the survey received antenatal care at least once for the last live birth from a health professional, that is, a doctor, or nurse/midwife (MoHP: Population Division, New ERA, MEASURE DHS and U.S. Embassy, August 2011).

Out of total 38 respondents, $79 \%$ reported use iron tablets during the pregnancy and after post-delivery periods also.

\begin{tabular}{|c|c|c|c|c|c|c|}
\hline \multicolumn{7}{|c|}{ Table 3. Use of Iron Tablets } \\
\hline \multirow{2}{*}{ Caste/Ethnicity } & \multicolumn{2}{|c|}{ Less than Three Months } & \multicolumn{2}{|c|}{ Post Delivery Days } & \multicolumn{2}{|c|}{ Total } \\
\hline & \# & $\%$ & \# & $\%$ & $\#$ & $\%$ \\
\hline Brahman/Chhetri & - & - & 3 & 100 & 3 & 10 \\
\hline Ethnic Group & 5 & 33 & 10 & 66 & 15 & 50 \\
\hline Chepang & 7 & 64 & 4 & 36 & 11 & 37 \\
\hline Dalit & - & - & 1 & 100 & 1 & 3 \\
\hline Total & 12 & 40 & 18 & 60 & 30 & 100 \\
\hline
\end{tabular}

Field Survey, 2013

As compared to the hospital visit, the number of user of iron tablets were found high. Only 11 respondents of ethnic group reported to visit hospital but 15 reported that they had used the Iron tablets followed by only 2 Chepang reported about the visit of hospital but 11 had taken iron tablets and 1 respondent from Dalit had also reported about the use of iron tablet.

The prevalence of Anemia among pregnant women in Nepal is alarmingly high at $75 \%$. The most important cause of anemia during pregnancy is an inadequate dietary intake of iron.

Nepal also launched a programme in 2003 using community-based providers to distribute IFA supplements. Phase one of this programme was launched in five priority districts in 2003 with external financial and technical support. Baseline (2003), interim 1 (2004), interim 2 (2005) and end line surveys (2006) were done to evaluate the programme outcomes. Coverage during the second and third trimesters of pregnancy and postpartum increased from 27, 47 and 23\% at baseline respectively to 73,84 , and $73 \%$ at end line (Figure 2). Similarly, compliance among women in the second and third trimesters of pregnancy and during postpartum increased from 9, 29, and $8 \%$ at baseline respectively to 31,76 , and 36 percent at end line (Figure 3). Compliance was defined as consumption of at least $80 \%$ of prescribed IFA tablets. Deworming of pregnant women also increased from 2 percent at baseline to 43 percent at end line. Likewise, postpartum vitamin A supplementation increased from 26 percent to 70 percent (S Pandey, 2006).

It is reported that respondents had taken the iron tables either from the female community health volunteer (FCHV) or from the private clinic. They are aware about the use of iron tablets.

Participants were asked about their birthing places also (Table 4).

Table 4. Birthing Place

\begin{tabular}{|l|l|l|}
\hline Caste/Ethnicity & Home & Hospital \\
\hline
\end{tabular}




\begin{tabular}{|l|l|l|l|l|}
\hline & $\#$ & \% & $\#$ & $\%$ \\
\hline Brahman/Chhetri & 2 & 67 & 1 & 33 \\
\hline Ethnic Group & 11 & 73 & 4 & 27 \\
\hline Chepang & 18 & 95 & 1 & 5 \\
\hline Dalit & - & - & 1 & 100 \\
\hline Total & 31 & 82 & 7 & 18 \\
\hline
\end{tabular}

Field Survey, 2013

The data show that $82 \%$ reported that they had given birth to child at home followed by $18 \%$ reported that they had visited hospital for delivery. Comparatively, 95\% Chepang had given birth at home followed by $73 \%$ ethnic group and $67 \%$ Brahman/Chhetri. It shows that higher numbers of

\begin{tabular}{|l|l|l|l|l|l|l|l|l|}
\hline Table 5. Height of Children & \multicolumn{9}{|l|}{$\mathbf{6 0} \mathbf{~ c m}$} & $\mathbf{6 0 - 8 0} \mathbf{~ c m}$ & $\mathbf{8 0 - 1 0 0} \mathbf{~ c m}$ & \multicolumn{1}{l|}{$\mathbf{1 0 0} \mathbf{~ c m}$} \\
\hline \multirow{2}{*}{ Caste/Ethnicity } & $\#$ & $\mathbf{\%}$ & $\#$ & $\mathbf{6}$ & $\#$ & $\mathbf{\%}$ & $\#$ & \% \\
\hline Brahman/Chhetri & - & - & - & - & 3 & 75 & - & - \\
\hline Ethnic Group & - & - & 1 & 7 & 12 & 80 & 2 & 13 \\
\hline Chepang & 1 & 5 & 1 & 5 & 14 & 75 & 3 & 15 \\
\hline Dalit & - & - & - & - & 1 & 100 & - & - \\
\hline Total & 1 & 3 & 2 & 5 & 30 & 79 & 5 & 13 \\
\hline
\end{tabular}

Chepang's mothers are in risk of unsafe delivery.

The results of previous study conducted by Pradhan in 2005 in Kathmandu showed that $66 \%$ of the deliveries occurred in hospital and assisted by the doctors. And $34 \%$ were the home deliveries, among which $26 \%$ were assisted by the family or relatives and $8 \%$ by the traditional birth attendants (TBA) (Pradhan, 2005). As the data compared between the Kathmandu and Makwanpur district, institutional based delivery is found higher in practices in Kathmandu than Makwanpur. In 2005, there was 66\% in Kathmandu but in 2013, there is only 18\% in Makwanpur.

Children were also taken for study to know their health status. Height of 3-5 years children were measured (table 5).

The Table 5 shows that $3 \%$ children's height was less than $60 \mathrm{~cm}$ followed by $5 \%$ height was $60-80 \mathrm{~cm}, 79 \%$ height was $80-100 \mathrm{~cm}$ and $13 \%$ height was more than $100 \mathrm{~cm}$. as compare among the different caste groups, $15 \%$ Chepang children's height was more than $100 \mathrm{~cm}$ followed by $13 \%$ ethnic groups.

Weight of 3-5 years children was taken to know their physical health (Table 6).

\begin{tabular}{|c|c|c|c|c|c|c|}
\hline \multicolumn{7}{|c|}{\begin{tabular}{|l} 
Table 6. Weight of Children (in Kg) \\
\end{tabular}} \\
\hline \multirow{2}{*}{ Caste/Ethnicity } & \multicolumn{2}{|c|}{$9-12 \mathrm{~kg}$} & \multicolumn{2}{|c|}{$12-15 \mathrm{~kg}$} & \multicolumn{2}{|c|}{$15-20 \mathrm{~kg}$} \\
\hline & \# & $\%$ & $\#$ & $\%$ & \# & $\%$ \\
\hline Brahman/Chhetri & 2 & 67 & 1 & 33 & - & - \\
\hline Ethnic Group & 5 & 33 & 9 & 60 & 1 & 7 \\
\hline Chepang & 8 & 42 & 9 & 47 & 2 & 11 \\
\hline Dalit & - & - & 1 & 100 & - & - \\
\hline Total & 15 & 39 & 20 & 53 & 3 & 8 \\
\hline
\end{tabular}

Field Survey, 2013

The above data show that $39 \%$ children weight was $9-12 \mathrm{~kg}$ followed by $53 \%$ were $12-15 \mathrm{~kg}$ and $8 \%$ were from $15-29 \mathrm{~kg}$. Comparatively, weight of Chepang children was better than others. $11 \%$ Chepang children's weight was found $15-20 \mathrm{~kg}$ followed by $7 \%$ ethnic groups' children.

Similarly, thickness of arm was also measured among the 3-5 years children (table 7).

Table 7. Thickness of Arm (in cm)

\begin{tabular}{|l|l|l|l|}
\hline Caste/Ethnicity & $12-14 \mathrm{~cm}$ & $14-16 \mathrm{~cm}$ & $16-18 \mathrm{~cm}$
\end{tabular}




\begin{tabular}{|l|l|l|l|l|l|l|}
\hline & $\#$ & $\mathbf{\%}$ & $\#$ & \% & $\#$ & \% \\
\hline Brahman/Chhetri & 2 & 67 & 1 & 33 & - & - \\
\hline Ethnic Group & 5 & 33 & 8 & 54 & 2 & 13 \\
\hline Chepang & 4 & 21 & 10 & 53 & 5 & 26 \\
\hline Dalit & - & - & 1 & 100 & - & - \\
\hline Total & 11 & 29 & 20 & 53 & 7 & 18 \\
\hline
\end{tabular}

Field Survey, 2013

The data report that, $53 \%$ children's arm was $14-16 \mathrm{~cm}$ thick followed by $29 \%$ were $12-14 \mathrm{~cm}$ and $18 \%$ were $16-18 \mathrm{~cm}$. Regarding the thickness of arm also, 26\% Chepang children's arm was found $16-18 \mathrm{~cm}$ followed by $13 \%$ ethnic group.

In general, the nutritional status of children in Nepal has improved over the last decade. Fifty seven percent of children were stunted in 2001 compared with 41 percent in 2011 and 43 percent of children were underweight in 2001 compared with 29 percent in 2011. However, the proportion of children who are wasted declined only slightly from 13 percent in 2006 to 11 percent in 2011 (MoHP: Population Division, New ERA, MEASURE DHS and U.S. Embassy, August 2011).

Chepang children were found better in health status than Brahman/Chhetri and ethnic groups regarding the weight, height and thickness of arm of children. As the comparison of health checkup practices of mother during the pregnancy, frequency of hospital visit was high among Brahman/Chhetri community but health status of children were found better among the Chepang community.

\section{CONCLUSION}

The result of pilot study became more interesting regarding the health seeking practices of mothers during the pregnancy and post-delivery, and health status of children. On the one hand, health seeking practices was found better among the mothers of Brahmin/Chhetri communities but physical health status of 3-5 years children of Chepang communities found better than Brahmin/Chhetri. There may have other influencing factors of health status than only health seeking practices which need to be explored in further research.

\section{BIBLIOGRAPHY}

Department of Health Services. (2011). Annual Report. Department of Health Services. Kathmadu: Government of Nepal Ministry of Health and Population.

Limbu, P. a. (2011). Chepang food culture: contribution of wild edible and neglected plant species. Local Initiatives for Biodiversity. Pokhara, Nepal: Research and Development (LI-BIRD).

MoHP: Population Division, New ERA, MEASURE DHS and U.S. Embassy. (August 2011). NEPAL DEMOGRAPHIC AND HEALTH SURVEY 2011. Kathmandu Nepal: USAID, New ERA and Government of Nepal.

Park, K. (2007). Prevention and Social Medicine (19th ed.). Prem Nagar Jabalpur: Banarisider Bhanot.

Pradhan, A. (2005). Situation of antenatal care and delivery practices. Kathmandu University Medical Journal, Vol. 3, No. 3 (Issue 11), 266-270.

S Pandey, M. M. (2006). COMMUNITY-BASED INTEGRATED INTERVENTIONS IMPROVE COVERAGE OF AND COMPLIANCE WITH IRON SUPPLEMENTATION IN NEPALI WOMEN.

Micronutrient

Initiative/http://www.micronutrient.org/CMFiles/What\%20we\%20do/Folic\%20Acid/Poster-

2-Sarada-Pandey-Iron.pdf. 